NBER WORKING PAPER SERIES

\title{
EXCHANGE TRADED FUNDS: A NEW INVESTMENT OPTION FOR TAXABLE INVESTORS
}

\author{
James M. Poterba \\ John B. Shoven \\ Working Paper 8781 \\ http://www.nber.org/papers/w8781 \\ NATIONAL BUREAU OF ECONOMIC RESEARCH \\ 1050 Massachusetts Avenue \\ Cambridge, MA 02138 \\ February 2002
}

We are grateful to Yingcong Lan for excellent research assistance, and to Daniel Bergstresser, Rob Engle, Burton Malkiel, and especially Joel Dickson and John Rea for many helpful discussions. The Hoover Institution, the National Science Foundation, and the Finance Program of the Stanford Institute for Economic Policy Research provided us with research support. The views expressed herein are those of the authors and not necessarily those of the National Bureau of Economic Research.

(C) 2002 by James M. Poterba and John B. Shoven. All rights reserved. Short sections of text, not to exceed two paragraphs, may be quoted without explicit permission provided that full credit, including (C) notice, is given to the source. 
Exchange Traded Funds: A New Investment Option for Taxable Investors

James M. Poterba and John B. Shoven

NBER Working Paper No. 8781

February 2002

JEL No. H24, G23, G24

\begin{abstract}
Exchange traded funds (ETFs) are a new variety of mutual fund that first became available in 1993. ETFs have grown rapidly and now hold nearly $\$ 80$ billion in assets. ETFs are sometimes described as more "tax efficient" than traditional equity mutual funds, since in recent years, some large ETFs have made smaller distributions of realized and taxable capital gains than most mutual funds. This paper provides an introduction to the operation of exchange traded funds. It also compares the pre-tax and post-tax returns on the largest ETF, the SPDR trust that invests in the S\&P500, with the returns on the largest equity index fund, the Vanguard Index 500. The results suggest that between 1994 and 2000, the before- and after-tax returns on the SPDR trust and this mutual fund were very similar. Both the after-tax and the pre-tax returns on the fund were slightly greater than those on the ETF. These findings suggest that ETFs offer taxable investors a method of holding broad baskets of stocks that deliver returns comparable to those of low-cost index funds.
\end{abstract}

James M. Poterba

Department of Economics

E52-350

MIT

50 Memorial Drive

Cambridge, MA 02142-1347

and NBER

617-253-6673

poterba@mit.edu
John B. Shoven

Department of Economics

Stanford University

Stanford, CA 94305

and NBER

650-326-5377

shoven@leland.stanford.edu 
Exchange traded funds (ETFs) are a rapidly growing class of financial products. ETFs are typically organized as unit trusts. They were introduced in 1993, and by the end of 2001, they held $\$ 79$ billion in assets -- 2.4 percent of the total assets in equity mutual funds. The share of equity mutual fund assets held through ETFs doubled in 2000 and rose by nearly fifty percent in 2001. With several years of continued growth at this pace, the assets held through ETFs will rival the amount held in equity index funds.

Exchange traded funds are of interest to public finance researchers concerned with taxation and portfolio behavior for two reasons. First, they represent new financial innovations that are sometimes described as prototypes for the future evolution of the mutual fund industry. It is therefore important to understand their tax treatment and their after-tax returns. Second, ETFs are often promoted as being more "tax efficient" than traditional equity mutual funds. By reducing the tax burden on investments in corporate stocks, relative to investments in such stocks held through equity mutual funds, ETFs may therefore move closer to the consumption-tax treatment of corporate capital income.

In this brief paper, we compare the pre-tax and after-tax return on the largest exchange traded fund, the SPDR trust that holds the securities in the S\&P500, with the returns on the largest equity index fund, the Vanguard Index 500 fund. This fund tracks the same index as the SPDR trust. We extend the ETF return calculations of Elton, Gruber, Comer, and Li (2000) by focusing on a longer sample period and by comparing ETF returns with those on index funds.

Mutual funds are subject to specialized tax rules. In particular, they must pass through realized capital gains to their shareholders. Dickson and Shoven (1995) and Dickson, Sialm, and Shoven (2000) emphasize that this raises the tax burden on mutual fund investors relative to the tax burden on a buy-and-hold portfolio of securities. When a fund manager sells appreciated 
shares, buy-and-hold investors in an equity mutual fund may become taxable on the fund's realized capital gains. Exchange traded funds are technically mutual funds, so they are governed by the same tax rules, but they have used a technique known as "redemption in kind" to substantially reduce or even eliminate their distributions of realized capital gains. This accounts for their historical tax advantage relative to many traditional equity mutual funds.

\section{The Mechanics of Exchange Traded Funds}

ETFs are traded securities. Gastineau $(2001,2002)$ provides a very detailed history of both the history of ETFs, and the current operation of these products. The first ETFs were traded on the American Stock Exchange, although ETFs are now traded on the New York Stock Exchange as well. Each ETF share is a claim on a trust that holds a specified pool of assets. The SPDR trust, for example, holds the stocks in the S\&P500. ETF shares are created when an authorized financial institution deposits a portfolio of securities with the trustee and receives ETF shares in return. These ETF shares can be sold to other investors. The market for ETF shares operates like the market for shares of a common stock. Investors can buy or sell ETF shares at any point during the day. ETF share prices may diverge from the underlying net asset value (NAV) of the securities held in the trust, although such divergence is restricted by the capacity of authorized financial institutions to create and redeem ETF shares. If the ETF share

price rises too far above the NAV for the underlying assets, the creating institutions will buy the associated securities, deposit them in the trust, and create new ETF shares. If the ETF share price falls below the NAV of the underlying assets, institutions will purchase ETF shares and redeem them for the underlying securities.

ETF shares must be purchased through brokerage firms, which entails commission costs. They can be purchased on margin and sold short. These features, as well as the opportunity to trade ETF shares throughout the day, distinguish ETFs from shares in traditional equity mutual 
funds. Mutual funds can only be bought or sold at their end-of-day net asset value. In many cases they can be purchased without any commission, directly from the fund complex. Mutual fund shares cannot be sold short or bought on margin. These differences suggest that ETFs and mutual fund shares may be appropriate for different types of investors: ETFs for investors who demand short-term liquidity and who buy in large lots, equity mutual funds for investors who make many small purchases or sales and who place less value on liquidity.

The foregoing differences notwithstanding, ETFs are similar to mutual funds in many ways. Both have operating expenses that reduce investor returns. Most ETFs to date have been designed to track a specified market index, so they are similar to equity index funds. Both ETFs and index funds may experience some "tracking error" in matching the pre-tax return on the index. ETF and mutual funds can differ in their expense ratios, their tracking error, and, because of the bid-ask spread on the ETF, in the relationship between their purchase price and the net asset value of the underlying index securities. On an after-tax basis, differences in capital gain realizations between ETFs and equity index funds may also lead to differences in returns.

Table 1 presents information on the growth of ETFs, equity index funds, and all equity mutual funds during the last decade. The first column shows that between 1993, when ETFs were first introduced, and 2000, the assets held by equity mutual funds rose roughly five-fold. Over the same period, the assets of domestic index funds rose by a factor of fifteen. Index funds represented three percent of the assets in equity mutual funds in 1993, compared with nearly nine percent in 2000. The growth in ETFs is even more dramatic. ETFs had virtually no assets in 1993, but by year-end 2000, they accounted for 1.7 percent of equity mutual fund assets. This share had grown to 2.3 percent by November 2001 .

ETF assets are highly concentrated. Table 2 shows that at the end of 2001, eight ETFs had at least $\$ 1.5$ billion in assets. The two largest funds, the SPDR trust (ticker symbol SPY) 
and the NASDAQ 100 trust (ticker symbol QQQ) trust, accounted for more than $\$ 51$ billion in ETF assets, or nearly three quarters of the total. Table 2 also shows that the expense ratios charged on the largest funds vary from nine basis points (iShares S\&P500) to 28 basis points (SPDR Technology). In general, the expense ratios on ETFs that invest in specific industries or in indices that include non-U.S. stocks are higher than the expense ratios for ETFs that hold only domestic securities. The expense ratios for most of the large ETFs, however, are substantially below the expense ratios for equity mutual funds, even those for index funds. Data compiled by

the Investment Company Institute suggest that in 1998, the asset-weighted average expense ratio for domestic equity index funds was 24 basis points ( 0.24 percent) per year.

\section{Comparing Returns on ETFs and Index Funds}

To illustrate the differences in the before-tax and the after-tax returns on ETFs and traditional equity mutual funds, consider a taxable investor who faces a tax rate of $\tau_{\mathrm{d}}$ on dividend income and $\tau_{\mathrm{cg}}$ on realized long-term capital gains. Assume that all realized gains are long term. For investors who do not liquidate their holdings, the pretax return (R) on both ETFs and mutual funds consist of three components: $\mathrm{R}=\mathrm{d}+\mathrm{g}+\mathrm{u}$. In this expression, $\mathrm{d}$ denotes dividend income, g denotes realized capital gains distributed by the ETF or the fund, and u denotes unrealized capital gains. All three of these return components are measured as percentages of the beginning of period value of the fund or the ETF. For the fund this would be measured using NAV, while for the ETF, the initial value could be measured using either NAV or the market price of ETF shares.

Table 3 presents information on the return to holding an S\&P500 portfolio by holding the SPDR exchange-traded fund and by holding the retail Vanguard Index 500 fund. The table also shows the returns on the index itself. We consider the retail version of the Vanguard index fund, which has higher expenses than the institutional fund for clients with large portfolios. 
We calculate returns on the SPDR trust in two ways. The first measures annual undistributed capital gains as the difference between the net asset value of the SPDR trust at the beginning and at the end of the year. The second measures undistributed capital gains as the difference between the closing prices for the shares in the SPDR trust over the same period. The NAV and closing price can differ for the ETF. Table 3 shows that on average, the total pretax return for a SPDR trust investor was 16 or 17 basis points, depending on our measure of undistributed capital gains, below the return on the Vanguard Index 500. This fund in turn had an average return that was six basis points lower than the return on the S\&P 500 Index. The return differential between the index fund and the index is smaller than the index fund's expense ratio. This indicates that the Vanguard Index 500 fund outperformed the index during our sample period. The superior performance of the index fund may be due to various trading strategies with positive average returns, such as purchasing shares in companies that are being added to the S\&P 500 when their addition is announced, rather when the addition actually takes place.

The 22 or 23 basis point shortfall between the average return on the SPDR trust and the return on the S\&P 500 Index is explained by two primary factors. First, the expense ratio for the SPDR exchange traded fund averaged 17 basis points over the seven-year period we consider. Second, when an ETF receives dividend payments, they are held in a non-interest-bearing cash account until the end of each quarter, at which point they are distributed to investors. Elton, Gruber, Comer, and Li (2000) observe that in a rising market, like that experienced during much of our sample period, the delay in reinvesting dividends will cause the return on the ETF to fall below that on the market index or on index funds that reinvest dividends immediately.

The calculations in Table 3 suggest that the average return on the SPDR trust has been close to the average return on the S\&P 500 index, and that it has been within twenty basis points of the average pretax return on the lowest-cost retail index fund. The average ETF return would be 
closer to the average return on all index funds, since other retail index funds have higher expense ratios than the Vanguard Index 500. The disparity between the ETF return and the index fund return would be larger if we considered an institutional index fund, such as Vanguard Admiral shares, which charge an expense ratio of 12 rather than 18 basis points.

Table 3 shows that while the average return on the SPDR trust tracks the average S\&P 500 return, there are non-trivial year-to-year differences. The difference between the closing price and the NAV on ETFs can generate differences between the ETF return calculated using closing prices and the return on the index fund or the S\&P 500 index. In 1999, for example, there was nearly a 60 basis point difference between the ETF return calculated using closing prices and that calculated using the net asset value at the beginning and end of the year.

\section{Taxes and Transactions Costs}

The current-year after-tax return for a buy-and-hold investor in either an ETF or an index fund is $\mathrm{R}_{\mathrm{at}}=\left(1-\tau_{\mathrm{d}}\right)^{*} \mathrm{~d}+\left(1-\tau_{\mathrm{cg}}\right)^{*} \mathrm{~g}+\mathrm{u}$. Bergstresser and Poterba (2002) note that unrealized gains in fact face a tax burden that in present discounted value is some fraction of the current statutory tax rate. Assuming a zero tax rate on undistributed gains probably overstates the effective after-tax return differences between the SPDR trust and the Vanguard Index 500.

The average capital gain distribution on the SPDR trust, as a percentage of the beginningof-year trust value, has been three basis points per year over the 1993-2000 period. For the Vanguard Index 500 fund, the average capital gain distribution has been 48 basis points. For a taxable investor facing a 20 percent marginal tax rate on realized capital gains, the after-tax return on the index fund would be reduced, relative to that on the SPDR, by roughly nine basis points.

Table 4 shows the before-tax and the after-tax geometric mean return on both the SPDR and the Vanguard Index 500 fund over the 1994-2000 period. Before tax, the return on the Vanguard Index 500 is 21.5 basis points higher than the return on the ETF. This value is different 
from the value in Table 3, which focuses on the arithmetic mean return. For an investor facing an income tax rate of $39.6 \%$ on dividend income, and $20 \%$ on long-term capital gain realizations, the after-tax return on the Vanguard Index 500 is 17.2 basis points higher than that on the SPDR trust. If the investor faces a lower marginal tax rate, $28 \%$ on ordinary income, then the return differential is 17.9 basis points in favor of the Vanguard Index 500 fund. These modest differences suggest that the higher tax burden associated with the greater capital gain distributions on the Index 500 fund, relative to the SPDR ETF, do not reduce the after-tax return by enough to outweigh the pretax return advantage of the index fund. The capital gain distributions of the Vanguard Index 500 fund are very low by comparison to other equity mutual funds, and even by comparison to other index funds. If we compared the SPDR with other index funds, the after-tax return benefits of low capital gain distributions would be magnified.

The calculations in Table 4 do not include all of the potential costs that an investor might face in purchasing an exchange traded fund. Investors must pay commission charges to a broker when they buy or sell ETFs. In addition, the bid-ask spread on ETFs raises the round-trip transaction cost. For the 1994-2000 period, the average difference between the bid and ask prices for the SPDR trust, as a percentage of the midpoint of the price range for each day, was 0.096 percent ( 9.6 basis points). This spread would essentially represent a one-time charge associated with trading in ETFs. Commission charges should be viewed in the same way - a one-time cost that reduces the return on the ETF investment.

We have not tried to calculate the effect of these transaction costs on the internal rate of return on the SPDR trust relative to that on the Vanguard Index 500. If an investor were holding the SPDR trust for only a single year, then the return would be reduced by the average bid-ask spread, or by another 9.6 basis points. Commission costs would further reduce the return, but the magnitude of this effect would depend on the size of the ETF purchase. Over longer holding 
periods, the transaction cost associated with the bid-ask spread has a more muted effect on the internal rate of return.

\section{In-Kind Redemptions and After-Tax Returns}

The SPDR trust has distributed fewer capital gains than the Vanguard Index 500 over our sample period. The difference in capital gain realization rates between ETFs and equity mutual funds has more generally been a key component of the marketing claim that ETFs are "tax efficient" relative to mutual funds. The experience of the SPDR trust is not representative of all ETFs -- many ETFs have distributed capital gains in recent years. However, the way ETF shares are created and redeemed provides ETFs with a means to lower their capital gain realizations relative to some traditional equity mutual funds.

When arbitrageurs redeem ETF shares from the trust, the trustee has the option of distributing the underlying securities that comprise the index, rather than cash, to the arbitraguer. This is known as "redemption in kind," and it is a strategy that is available to all investment companies operating under the terms of the Investment Company Act of 1940. Traditional equity mutual funds can also utilize redemption in kind, although they have historically used this option relatively infrequently. The greater use of this strategy by the ETFs reflects in part their greater frequency of large trades, as arbitrageurs create and redeem trust shares.

Redemption in kind offers the trustee the opportunity to reduce the value of unrealized capital gains held within the ETF trust. When the trustee distributes securities, he can choose to distribute securities with substantial embedded capital gains. When an arbitrageur redeems $\$ 100,000$ of ETF shares for $\$ 100,500$ of underlying stock, the capital gain for the arbitrageur is $\$ 500$. This is true even if the ETF distributes a basket of securities with a current market value of $\$ 100,500$, but a basis to the ETF of $\$ 50,000$. When the ETF distributes these securities with a basis below the market price, however, it eliminates the potential capital gains tax liability that 
ETF investors might face if these shares were sold, thereby triggering a pass-through of realized capital gains. Thus redemption in kind provides a way around the problem of embedded capital gains in open-end equity mutual funds. By distributing low-basis stock, the ETF reduces the likelihood that it will at some point need to sell low-basis stock and then distribute realized capital gains to its investors.

Redemption in kind is a powerful means of reducing embedded capital gains. As of September 30, 2000, for example, the SPDR trust held net assets of $\$ 24.29$ billion, capital loss carryforwards of $\$ 0.52$ billion, and unrealized capital losses of $\$ 1.06$ billion. Despite the fact that the trust had grown through a period of substantial market appreciation, it apparently had succeeded in distributing its low-basis securities and retaining higher basis holdings.

Redemption in kind is not the only factor leading to differences in capital gain realizations between the SPDR trust and the Vanguard Index 500. Because the SPDR trust was created in 1993, while the Vanguard Index 500 began trading in the 1970s, the distribution of purchase bases for the securities in the SPDR trust is different from that in the Vanguard fund. Such historical differences can lead to differences in realized gains and after-tax returns.

\section{$\underline{\text { 5. Further Issues }}$}

In future work, we hope to explore many issues associated with exchange traded funds. We hope to move beyond our analysis of the SPDR trust to consider the performance of other exchange traded funds. In October 2001, there were 96 exchange traded funds, compared with 79 one year earlier. Many of the new funds have specific investment objectives, such as holding stocks in a given sector or nation, and they also have substantially higher expense ratios than the SPDR trust. The mutual funds that these ETFs compete with are also likely to have substantially higher expenses than the Vanguard Index 500 fund. 
A second issue involves studying the attraction of ETFs and traditional open-end equity mutual funds for taxable investors with assets in both a taxable and a tax-deferred account. The low rate of taxable distributions on ETFs, and their liquidity, may make them more attractive for equity investments outside tax-deferred accounts than for investments in IRAs or 401(k)s. The attributes of traditional equity mutual funds may make them more attractive for retirement account investors.

Finally, we plan to consider how ETFs feature in the expanding mix of products offered by the mutual fund industry. ETFs may be part of an emerging trend toward segmentation of the mutual fund marketplace, with investors who wish to trade frequently segregated into different products than low-turnover investors. The former group may eventually hold funds with substantial expense ratios that cover the account management fees associated with high-turnover investors, while the low-turnover, or high account value, investors may be able to invest through funds with much lower costs. ETFs may attract investors who value the ability to trade frequently, thus reducing the turnover rate for the investors who continue to invest in traditional open end equity funds. 


\section{REFERENCES}

Bergstresser, Daniel and James Poterba. "Do After-Tax Returns Affect Mutual Fund Inflows?" Journal of Financial Economics (forthcoming).

Dickson, Joel and John Shoven. "Taxation and Mutual Funds: An Investor Perspective," in J. Poterba, ed., Tax Policy and the Economy, Volume 9. Cambridge: MIT Press, 1995, pp. 151-181.

Dickson, Joel, John Shoven, and Clemens Sialm. "Tax Externalities of Equity Mutual Funds." National Tax Journal, September 2000, 53 (3, Part 2), pp. 608-627.

Elton, Edwin J., Martin J. Gruber, George Comer, and Kai Li. "Spiders: Where are the Bugs?" Mimeo, Stern School of Business, New York University, 2000.

Gastineau, Gary. "Exchange Traded Funds: An Introduction." Journal of Portfolio Management 27 (Spring 2001), pp. 88-96.

Gastineau, Gary. The Exchange Traded Funds Manual. New York: John Wiley, 2002.

Investment Company Institute. "Exchange Traded Funds Statistical Collection." Washington, D.C.: Investment Company Institute, 2001a.

Investment Company Institute. Mutual Fund Fact Book. Washington, D.C.: Investment Company Institute, $2001 \mathrm{~b}$.

Investment Company Institute. "Redemption Activity of Mutual Fund Owners." Investment Company Institute Research in Brief, 10 (1), March 2001.

Standard and Poors Corporation. Monthly Review. New York: Standard and Poors, various issues. 
Table 1: Assets in Equity Mutual Funds and Exchange Traded Funds, 1994-2001

\begin{tabular}{|l|l|l|l|}
\hline Year & $\begin{array}{l}\text { Equity Mutual } \\
\text { Funds }\end{array}$ & $\begin{array}{l}\text { Domestic Equity } \\
\text { Index Funds }\end{array}$ & $\begin{array}{l}\text { Exchange Traded } \\
\text { Funds }\end{array}$ \\
\hline 1993 & 740.7 & 22.6 & 0.46 \\
\hline 1994 & 852.8 & 26.0 & 0.42 \\
\hline 1995 & 1249.1 & 47.0 & 1.05 \\
\hline 1996 & 1726.1 & 83.5 & 2.40 \\
\hline 1997 & 2368.0 & 147.9 & 6.70 \\
\hline 1998 & 2978.2 & 233.1 & 15.56 \\
\hline 1999 & 4041.9 & 344.0 & 33.86 \\
\hline 2000 & 3962.3 & 339.3 & 65.59 \\
\hline 2001 & 3348.7 & n.a. & 78.85 \\
\hline
\end{tabular}

Source: Authors' tabulations based on data from the Investment Company Institute (2001a, b). All entries except 2001 correspond to December of the indicated calendar year; 2001 data are for November.

Table 2: Exchange Traded Funds with More than \$1.5 Billion in Assets, December 31, 2001

\begin{tabular}{|l|l|l|l|}
\hline Fund Name & Assets (\$ Billion) & Launch Date & Expense Ratio \\
\hline SPDR Trust (SPY) & $\$ 30.4$ & $1 / 29 / 93$ & $0.12 \%$ \\
\hline $\begin{array}{l}\text { NASDAQ -100 } \\
\text { Trust (QQQ) }\end{array}$ & 21.8 & $3 / 09 / 99$ & 0.18 \\
\hline $\begin{array}{l}\text { S\&P Midcap 400 } \\
\text { Trust (MDY) }\end{array}$ & 4.8 & $5 / 4 / 95$ & 0.25 \\
\hline $\begin{array}{l}\text { IShares S\&P 500 } \\
\text { Index Fund (IVV) }\end{array}$ & 3.6 & $5 / 15 / 00$ & 0.09 \\
\hline $\begin{array}{l}\text { DOW Diamond } \\
\text { Series Trust I (DIA) }\end{array}$ & 3.0 & $1 / 27 / 98$ & 0.12 \\
\hline $\begin{array}{l}\text { IShares Russell } \\
\text { 2000 Index Fund }\end{array}$ & 2.1 & $5 / 22 / 00$ & 0.20 \\
\hline $\begin{array}{l}\text { HOLDRS Biotech } \\
\text { (BBH) }\end{array}$ & 1.6 & $11 / 22 / 99$ & $*$ \\
\hline $\begin{array}{l}\text { IShares Russell } \\
\text { 3000 Index Fund }\end{array}$ & 1.5 & $5 / 22 / 00$ & 0.20 \\
\hline
\end{tabular}

Source: Wall Street Journal January 7, 2002, page R17. * denotes a minimum expense ratio of eight cents per share. 
Table 3: Calendar Year Returns on S\&P 500 Index Funds, ETFs, and the S\&P500 Index

\begin{tabular}{|c|c|c|c|}
\hline & $\begin{array}{l}\text { Total Return, NAV } \\
\text { (Closing Price) }\end{array}$ & $\begin{array}{l}\text { Dividend Yield (\% of } \\
\text { Lagged Price) }\end{array}$ & $\begin{array}{l}\text { Distributed Capital Gains } \\
\text { (\% of Lagged Price* }\end{array}$ \\
\hline \multicolumn{4}{|c|}{ Exchange Traded Fund (SPY) } \\
\hline 1994 & $1.16 \%(0.67 \%)$ & $2.64 \%$ & $0.00 \%$ \\
\hline 1995 & $37.22(38.10)$ & 2.85 & 0.02 \\
\hline 1996 & $22.70(22.54)$ & 2.26 & 0.20 \\
\hline 1997 & $33.06(33.48)$ & 1.87 & 0.00 \\
\hline 1998 & $28.35(28.69)$ & 1.46 & 0.00 \\
\hline 1999 & $20.86(20.39)$ & 1.17 & 0.00 \\
\hline 2000 & $-9.15(-9.73)$ & 1.03 & 0.00 \\
\hline Average & $19.17(19.16)$ & 1.90 & 0.00 \\
\hline \multicolumn{4}{|c|}{ Vanguard Index 500 Fund } \\
\hline 1994 & 1.18 & 2.67 & 0.46 \\
\hline 1995 & 37.45 & 2.84 & 0.30 \\
\hline 1996 & 22.88 & 2.22 & 0.43 \\
\hline 1997 & 33.19 & 1.90 & 0.85 \\
\hline 1998 & 28.62 & 1.48 & 0.47 \\
\hline 1999 & 21.07 & 1.24 & 0.87 \\
\hline 2000 & -9.06 & 0.96 & 0.00 \\
\hline Average & 19.33 & 1.90 & 0.48 \\
\hline \multicolumn{4}{|c|}{ S\&P 500 Index } \\
\hline 1994 & 1.32 & 2.83 & $-1.54^{*}$ \\
\hline 1995 & 37.58 & 3.00 & $34.11^{*}$ \\
\hline 1996 & 22.96 & 2.42 & $20.26^{*}$ \\
\hline 1997 & 33.36 & 2.09 & $31.01 *$ \\
\hline 1998 & 28.58 & 1.67 & $26.67 *$ \\
\hline 1999 & 21.04 & 1.36 & $19.53 *$ \\
\hline 2000 & -9.10 & 1.11 & $-10.14 *$ \\
\hline Average & 19.39 & 2.07 & $17.13^{*}$ \\
\hline
\end{tabular}

Source: Data underlying calculations for the SPDR return at NAV and for the S\&P500 Index are drawn from the S\&P Monthly Review. SPDR closing price returns are computed from CRSP data. Data on the Vanguard Index 500 fund was collected from various fund reports to shareholders. * indicates that capital gains on the S\&P 500 Index are total capital gains, not distributed capital gains as in the case of the SPY and Vanguard Index Fund.

Table 4: After-Tax Returns for Taxable Investors in SPY and Vanguard Index 500, 1994-2000

\begin{tabular}{|l|l|l|l|}
\hline Return Measure & SPY (ETF) & Vanguard Index 500 & Difference \\
\hline Before-Tax & $17.982 \%$ & $18.197 \%$ & $0.215 \%$ \\
\hline $\begin{array}{l}\text { After-Tax with 39.6\% Ordinary } \\
\text { Income Tax Rate }\end{array}$ & 14.993 & 15.165 & 0.172 \\
\hline $\begin{array}{l}\text { After-Tax With 28\% Ordinary } \\
\text { Income Tax Rate }\end{array}$ & 15.227 & 15.406 & 0.179 \\
\hline
\end{tabular}

